No 2011 - 10

April

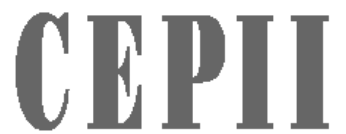

CENT TE

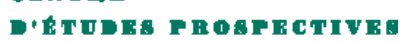

ET D'INFORMATIONS

INTEENATHONALE:

\title{
The Trade Unit Values Database
}

Antoine Berthou \& Charlotte Emlinger 
TABLE OF CONTENTS

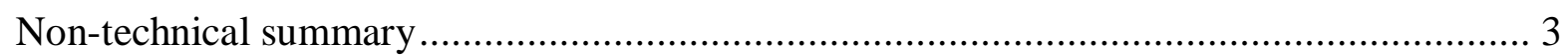

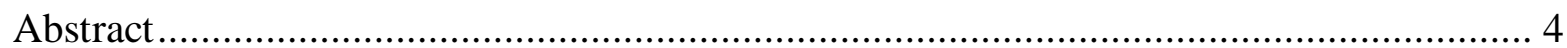

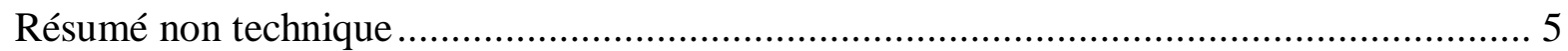

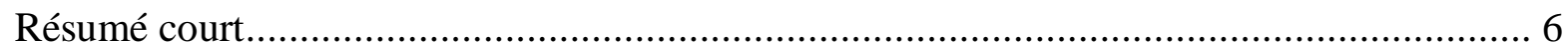

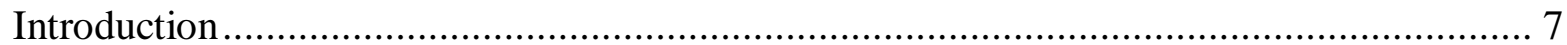

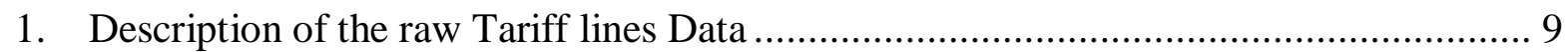

1.1. Nomenclature and level of disaggregation ............................................... 9

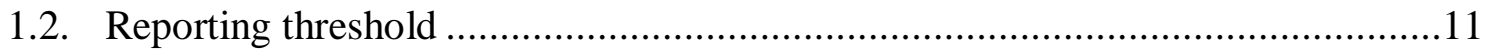

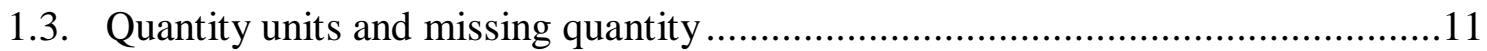

2. The processing methodology of the Trade $U$ nit $V$ alues database ...............................12

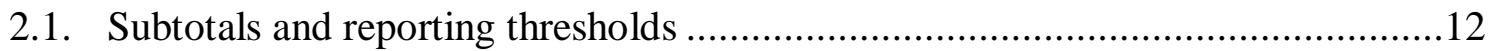

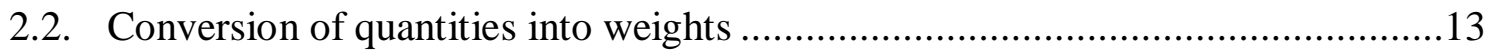

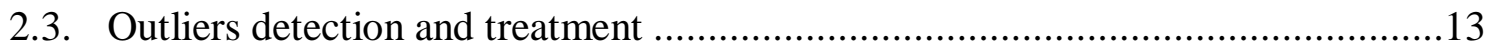

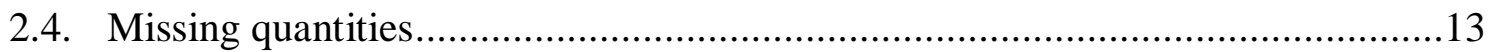

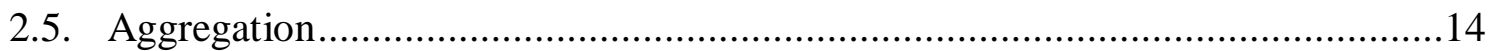

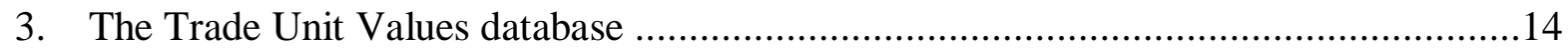

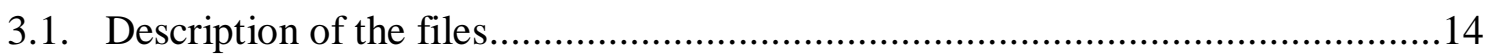

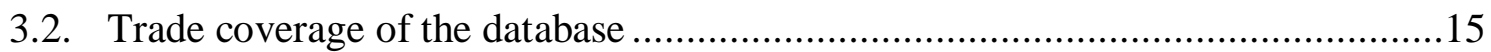

4. $V$ alidation tests of the Trade U nit $V$ alues database...................................................16

4.1. M ethodological differences with Comtrade..................................................16

4.2. Dispersion of unit values ...................................................................

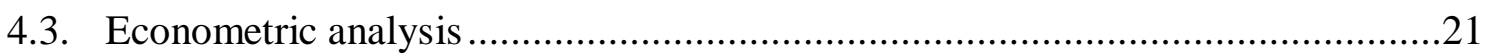

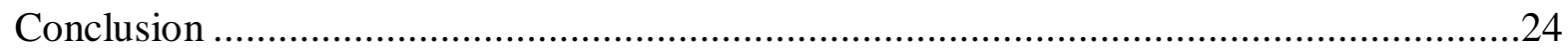

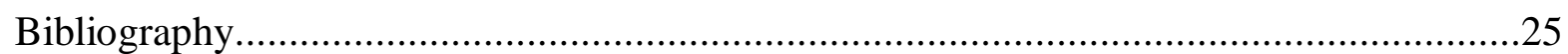

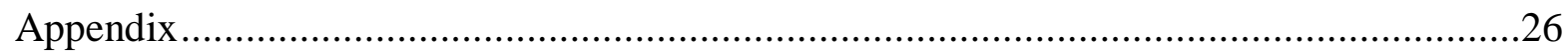

A 1. Country coverage in the Trade U nit V alue database ........................................26

A2. Summary of the quantity correction in Comtrade ................................................28

List of working papers released by CEPII ...................................................................... 
The Trade Unit Values Database

\section{NON-TECHNICAL SUMMARY}

Unit values are an essential tool in the toolbox of empirical trade and macro economists. They are used to approximate trade "prices", which are not available for a large number of countries, items and years. Trade unit values, however, can be computed as the ratio of values and quantities using international trade datasets with product disaggregation. A s their primary objective is to provide information about "trade", using these data to calculate trade unit values may be awkward. In particular, estimation of missing quantity information in worldwide trade dataset (aimed at improving countries coverage) reduces the reliability of unit values as a proxy for trade prices.

This paper presents a new, worldwide database, the Trade U nit Values dataset. Our methodology relies on the "Tariff lines" database of the United Nations Statistical Division, corresponding to the values and quantities of trade declared by individual countries to the UN. These data are processed in order to provide reliable and comparable unit values across countries. U nit values are computed for each reporter (which can be an exporter or importer), partner and product at the highest level of disaggregation reported in the Tariff lines database. This requires that all quantity units are converted into weights. Extreme unit values are detected using the cross-sectional and time dimensions of the data. Finally, unit values are aggregated at the HS 6-digits level, allowing international comparisons.

Overall, this strategy improves the reliability of unit values. We show that the Trade Unit $\checkmark$ alues database exhibits a higher dispersion of trade prices by product category, as compared to the UN Comtrade. Econometric estimations show that this higher dispersion is well explained by economic aggregates. The data can therefore be an interesting tool for performing international comparisons in terms of vertical specialization among product categories, or for analyzing the relation between macroeconomic aggregates and the pricing strategy of countries.

The final Trade U nit V alues database contains U nit V alue information (in US dollars per ton) over the period 2000-2008, with 173 reporters, 255 partners, and more than 5,000 product categories per year. The coverage changes over time. U nit values are ultimately provided in Harmonized System 1996 and 2002 revisions with 6 digits, Free on B oard (FOB) and Cost of Insurance and Freight (CIF). The CIF unit values rely on importers' declarations, and include all trade costs (except tariffs and domestic taxes after the border). The FOB unit value is a proxy for the trade price at the factory gate, relying on exporters' declarations, and does not include trade costs. 


\begin{abstract}
Trade unit values are commonly used as proxies for trade prices in empirical research in international economics. Existing datasets providing international trade unit values for a large number of countries typically suffer from a number of statistical biases, due to the aggregation of unit values and the harmonization of quantity information. These biases reduce the reliability of unit values as a proxy for trade prices. This paper presents the Trade U nit $V$ alues dataset, a new database developed to circumvent these statistical issues. B ilateral trade unit values are computed at a very high level of disaggregation before aggregation into Harmonized-System 6-digits categories to allow for cross-country comparability. Our processing strategy improves the differentiation of trade prices within product categories, as compared to existing worldwide datasets. A simple econometric analysis shows that unit values in our database are well explained by economic aggregates.
\end{abstract}

JEL Classification: E3; F1; F4

Key Words: $\quad$ Unit value, trade price, international trade 


\section{RÉSUMÉ NON TECHNIQUE}

L'analyse empirique de la spécialisation en gamme des pays exportateurs, de leur stratégie de prix ou des termes de l'échange nécessite de disposer de données de prix du commerce fiables et désagrégées. Les valeurs unitaires, qui correspondent au ratio des valeurs et des quantités du commerce sont généralement utilisés comme proxy de ces prix. Les bases de données de valeurs unitaires existantes présentes certaines limites. Beaucoup d'entre elles ne couvrent qu'un nombre restreint de pays. Dans le cas des bases internationales comme Comtrade, le traitement des quantités manquantes, visant à améliorer la couverture de la base, limite fortement la fiabilité des données quand il s'agit de calculer les valeurs unitaires.

Ce papier présente la nouvelle base de données Trade Unit Value du CEPII, qui a pour objectif de fournir des données de valeurs unitaires fiables et désagrégées pour la plupart des pays du monde. Cette base propose les valeurs unitaires du commerce en dollar par tonne pour 173 déclarants, 255 partenaires et plus de 5000 produits. Elle couvre actuellement la période 2000 à 2008. Les valeurs unitaires sont proposées dans deux révisions du système harmonisé (1996 et 2002) à 6 digits, en Coût A ssurance Fret (CAF) ou Free on B oard (FOB). Les données CAF sont issues des déclarations des importateurs et incluent tous les coûts au commerce à l'exception des droits de douane. Les valeurs unitaires FOB sont calculées à partir des déclarations des exportateurs et n'incluent ni coûts de transport ni assurances.

Les valeurs unitaires de la base Trade Unit Value sont calculées à partir de données de commerce en valeur et quantité fournies par la Division Statistique des Nations U nies. Ces données correspondent aux déclarations brutes des pays au Nations U nies et sont à un niveau de désagrégation des produits extrêmement fin, propre à chaque déclarant. Ces données ont été traitées afin de fournir des valeurs unitaires comparables entre pays et dans le temps. Dans un premier temps, les quantités, qui sont déclarées dans différentes unités, ont été converties en tonnes. Les valeurs extrêmes, issues d'erreurs de mesure ou de différents seuils de déclaration sont ensuite retirées de la base. Enfin, les valeurs unitaires sont agrégées au niveau 6 digit de la nomenclature harmonisée.

Les valeurs unitaires de la base Trade U nit V alue présentent une plus forte dispersion par catégorie de produit que valeurs unitaires qui peuvent être calculées à partir de la base de données Comtrade des $\mathrm{N}$ ations U nies. L'estimation d' une équation de gravité standard montre que cette plus forte dispersion s'explique par les agrégats économiques. La base de données Trade U nit $V$ alue constitue un outil intéressant pour les analyses empiriques que ce soit de la discrimination prix des pays exportateurs en fonction de leurs marchés de destination ou de la spécialisation verticale des pays par catégorie de produits. 


\section{RÉSUMÉ COURT}

L'analyse empirique du commerce international utilise généralement les valeurs unitaires comme proxy des prix du commerce. L'agrégation des valeurs unitaires et I'harmonisation des données de commerce en quantité limitent fortement la fiabilité des bases de données internationales de valeurs unitaires existantes. Ce papier présente la nouvelle base de données Trade U nit Value développée par le CEPII pour réduire ces biais statistiques. Les valeurs unitaires qu'elle propose ont été calculées à un niveau fin de la nomenclature des produits avant d'être agrégées au niveau 6 digits de la nomenclature harmonisée. Le traitement réalisé permet d'accroître la dispersion des prix du commerce à l' intérieur des catégories de produits, comparativement aux bases de données existantes. L'estimation d'une équation de gravité standard montre que cette plus forte dispersion s' explique par les agrégats économiques.

Classification J EL : E3, F1, F4

M ots-clefs : $\quad$ Valeur unitaire, prix du commerce, commerce international 
The Trade Unit VALUes Database ${ }^{1}$

A ntoine B erthou and Charlotte E mlinger ${ }^{*}$

\section{INTRODUCTION}

Trade prices are an essential tool to empirical research in international economics. They are used in a macroeconomic perspective to compute trade price indexes (B roda and Weinstein, 2006) and terms of trade, or to identify countries' specialization along a ladder of vertically differentiated varieties (Schott, 2008; Fontagné et al. 2008). Improvements of trade price data can take the form of a better coverage in terms of countries, the degree of disaggregation for which prices are available (goods, firms), and the reliability of the reported information.

Researchers usually have to arbitrate between two types of datasets. Firm-level datasets typically provide the unit value of one goods category sold on a market, by a firm, over a certain period of time. These data are, however, available for a limited number of countries with restricted access. ${ }^{2}$ Datasets such as the United Nations Comtrade database, or the E urostat Comext, offer a larger coverage in terms of countries, but loose the firm dimension. ${ }^{3}$ In all cases, trade "prices" are usually not available. Statistical institutes or researchers usually compute "unit values", which simply correspond to the ratio of the value and the quantity of shipments. The reliability of value and quantity is therefore directly affecting the approximation of "trade prices" with unit values. In the case of datasets covering trade flows among a large number of countries, harmonization is required to make national datasets as much comparable as possible. This processing, though improving the coverage and comparability of data, can be detrimental to the reliability of unit values as a proxy for trade prices.

This paper presents a new, worldwide database, the Trade U nit Values dataset. Our methodology relies on the "Tariff lines" database of the U nited Nations Statistical Division, corresponding to the values and quantities of trade declared by individual countries to the UN . These data are processed in order to provide reliable and comparable unit values across countries. U nit values are computed for each reporter (which can be an exporter or importer),

\footnotetext{
${ }^{1}$ We acknowledge financial support from A gFoodTrade. We thank M atthieu Crozet, Houssein Guimbard, Alix de Saint Vaulry and Lionel Fontagné for comments and suggestions. We are grateful to the U nited Nations Statistical Division for providing the tariff lines trade data, and for their helpful assistance.

*CEPII, 113 rue de Grenelle, 75007 Paris. Contact: antoine.berthou@ cepii.fr and charlotte.emlinger@ cepii.fr.

${ }^{2}$ See Bastos and Silva (2008) for Portugal; M anova and Zhang (2009) for China, M artin (2010) for France or Görg et al., (2010) for Hungary.

${ }^{3}$ For instance, Campa and Goldberg (2005) use Comext data to analyse the exchange rate pass-through in eurozone countries. Chang and Winters (2002) analyse the effect of regional agreements on import prices using UN COMTRADE.
} 
partner and product at the highest level of disaggregation reported in the Tariff lines database. This requires that all quantity units are converted into weights. Extreme unit values are detected using the cross-sectional and time dimensions of the data. Finally, unit values are aggregated at the HS 6-digits level, allowing international comparisons.

Our processing methodology aims at improving the reliability of unit values, as compared to existing unit values in trade datasets with World coverage such as the UN Comtrade. First, the processing that is implemented to develop the UN Comtrade dataset generates a complete dataset without missing quantity, when the value is available. $M$ issing quantities are estimated, notably using a unique standard unit value defined at the World level. When such estimation is implemented, this removes all the difference in prices across countries. Conversely, the Trade U nit V alues database does not rely on a World unit value to estimate quantity information, which enables to keep heterogeneity in terms of pricing across countries. Second, Comtrade aggregates separately values and quantities into HS 6-digits nomenclature. This can bias unit values when some of the quantity information is initially missing at a higher level of disaggregation. In our database, unit values, rather than the values themselves are computed at the highest level of disaggregation before aggregation in HS 6digits categories, thus reducing the bias due to separate aggregation of values and quantities.

Overall, this strategy is expected to provide a smaller coverage of unit values as compared with Comtrade, but improve the reliability of unit values. We show that the Trade U nit V alues database exhibits a higher dispersion of trade prices by product category, as compared to the UN Comtrade. Econometric estimations show, however, that this higher dispersion is well explained by economic aggregates. The data can therefore be an interesting tool for performing international comparisons in terms of vertical specialization among product categories, or for analyzing the relation between macroeconomic aggregates and the pricing strategy of countries.

The final Trade U nit V alues database contains U nit V alue information (in US dollars per ton) for the period 2000-2008 with a maximum of 173 reporters, 255 partners, and more than 5,000 product categories per year. Coverage improves over time. U nit values are ultimately provided in Harmonized System 1996 and 2002 revisions with 6 digits, Free on B oard (FOB) and Cost of Insurance and Freight (CIF). The CIF unit values rely on importers' declarations, and include all trade costs (except tariffs and domestic taxes after the border). The FOB unit value is a proxy for the trade price at the factory gate, relying on exporters' declarations, and does not include trade costs.

This paper starts with a presentation of the raw tariff lines data that are used to construct the unit values dataset. The second section describes the processing methodology that is used to construct HS 6-digits unit values. Section 3 presents the different files composing the database. Section 4 compares the Unit Values and Comtrade databases. Finally, Section 5 concludes. 


\section{DESCRIPTION OF THE RAW TARIFF LINES DATA}

The U nit V alue Database developed by the CEPII relies on Tariff lines data, provided by the United Nation Statistical Division. These data provide raw information on trade value and quantity as reported by the declaring country, for 173 reporters and 255 partner countries. Each country declares both imports (CIF) and exports (FOB).

Despite UN Statistical Division's recommendations to the declaring countries, a high heterogeneity remains in countries' declarations. Nomenclature of commodity codes, reporting thresholds and quantity units can differ across countries. Raw data also include subtotals and several flows can be associated with a given exporter, importer, product, and year (flows are duplicated). Considerable cleaning is therefore required before the construction of the dataset. In this section, we provide a description of the raw tariff line data.

\subsection{Nomenclature and level of disaggr egation}

The Harmonized System nomenclature with 6-digit product codes is commonly used for reporting trade flows (both exports and imports) by most countries in the World. Countries also often add one or more digits to HS product code. While this improves the detail in the nature of the products traded, this removes the comparability of trade flows across countries. Table 1 illustrates in how additional detail in the product nomenclature is materialized into products, with the example of wind musical instruments in the US classification. 6-digit categories can obviously contain products which are highly different by nature.

Table 1. W ind musical instruments in the US product classification

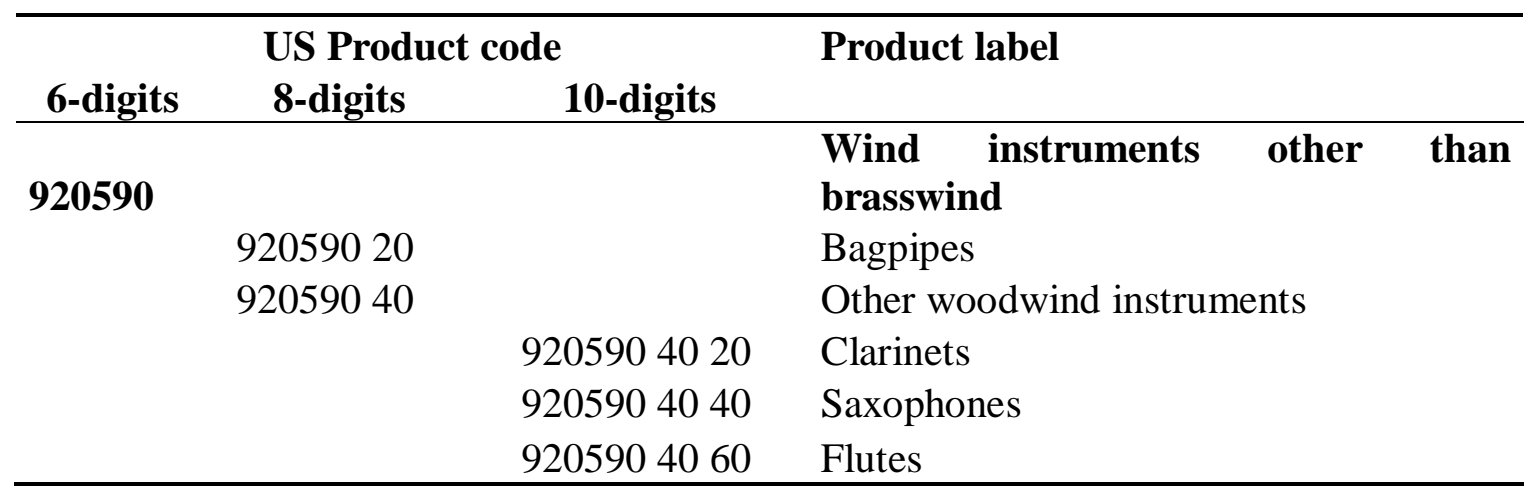

Sources: US Census Bureau.

The average level of disaggregation by country in the database corresponds to the 8-digit level, but some countries, like Turkey, use a very detailed country code system (Table 2 below). A few countries, like A ruba or Bermuda, declare using commodity code of 4 digits. In this case, trade flows do not match to the 6 -digit HS nomenclature and cannot be compared with other countries' flows. Though, more digits do not necessarily mean that more products 
are available in the country classification. For example, Turkey reports more digits in product codes in comparison to Canada, but has fewer products.

Table 2. Level of disaggregation and number of commodity codes by country in the tariff line database (I mport C IF database 2007).

\begin{tabular}{ccc}
\hline & Number of Digits & Number of products \\
\hline M ean & 8 & 5,920 \\
M edian & 8 & 5,327 \\
M aximum & 12 (T urkey) & 18,250 (Canada) \\
M inimum & 4 (A ruba) & 303 (A ruba) \\
\hline
\end{tabular}

Source: Tariff line Database, United N ations Statistical Division

The Harmonized System nomenclature was revised several times since its introduction in 1988. Each revision differs from the previous one by distinguishing new products or aggregating others. At a higher level of disaggregation, the frequency of revisions is even higher. Consequently, the Tariff line database has several revisions (rev0, rev1, rev2 and rev3) of the HS for a given year (table 3). For example, in 2007, the majority of countries (109) declared in the revision 3 of the HS, which corresponds to $93.23 \%$ of trade but 36 countries still declared in revision 1 . Up to 3 countries did not declare in a HS revision but in SITC.

Table 3. Share in world trade (number of countries) by revision of the Harmonized System in the tariff line database

\begin{tabular}{ccccccccccccc}
\hline & \multicolumn{3}{c}{$\mathrm{H} 0$} & \multicolumn{3}{c}{$\mathrm{H} 1$} & \multicolumn{2}{c}{$\mathrm{H} 2$} & \multicolumn{3}{c}{$\mathrm{H3}$} & \multicolumn{3}{c}{$\mathrm{S} 3$} \\
\hline 2008 & 0.01 & $(3)$ & 0.73 & $(10)$ & 6.03 & $(32)$ & 93.23 & $(109)$ &. &. \\
2007 & 0.18 & $(7)$ & 0.91 & $(13)$ & 10.64 & $(65)$ & 88.27 & $(77)$ &. &. \\
2006 & 0.18 & $(7)$ & 1.18 & $(19)$ & 98.62 & $(142)$ &. &. & 0.02 & $(1)$ \\
2005 & 0.17 & $(7)$ & 1.55 & $(23)$ & 98.25 & $(139)$ &. &. & 0.02 & $(1)$ \\
2004 & 0.18 & $(10)$ & 1.82 & $(26)$ & 97.97 & $(98)$ &. &. & 0.03 & $(1)$ \\
2003 & 0.19 & $(8)$ & 2.32 & $(30)$ & 97.41 & $(71)$ &. &. & 0.08 & $(2)$ \\
2002 & 0.17 & $(8)$ & 4.39 & $(36)$ & 95.20 & $(51)$ &. &. & 0.24 & $(3)$ \\
2001 & 0.40 & $(10$ & 99.24 & $(74)$ &. &. &. &. & 0.35 & $(3)$ \\
2000 & 0.33 & $(10)$ & 99.38 & $(66)$ &. &. &. &. & 0.30 & $(2)$ \\
\hline
\end{tabular}

Source: Tariff line Database, U nited Nations Statistical Division 


\subsection{Reporting threshold}

Trade values at the tariff line level are converted into dollars by the UN Statistical Division. The reporting threshold generally depends on the national currency and thus varies from one country to another. Having different minimum thresholds reduces the comparability across countries, since a given flow may appear or not in the dataset according to national practices. Table 4 reports the statistics concerning this threshold. The reporting threshold is low with a median of one dollar. Declarations with values equal to zero are observed in the database for R wanda or Poland.

Table 4. Reporting threshold in the tariff lines database (dollars)

\begin{tabular}{cc}
\hline & reporting threshold \\
\hline M ean & 83 \\
M edian & 1 \\
M aximum & 37,830 (Syrian A rab R epublic) \\
M inimum & 0 \\
\hline
\end{tabular}

Source: Tariff line Database, U nited N ations Statistical Division

\subsection{Quantity units and missing quantity}

Declaring countries use different quantity units according to the products. Eight differentquantity units are observed in the Tariff line database: kilograms, meters, squared meters, thousand of kilowatt-hour, units, pairs, thousands of units. Declarations in kilograms correspond to almost $60 \%$ of the total value of trade in the database for 2007 (Table 5). A high heterogeneity is observed across countries concerning the quantity units. Germany, for example, declares almost all its trade in kilograms, but only $19.5 \%$ of the US imports are declared in this unit. 
Table 5. Q uantity units by country, share of trade in value (CIF data in 2007).

\begin{tabular}{cccccccccc}
\hline & World & Brazil & China & France & Germany & Italy & India & $\begin{array}{c}\text { United } \\
\text { Kingdo } \\
\mathrm{m}\end{array}$ & USA \\
\hline no quantity & 8.9 & 13.56 & 1.29 & 3.01 & 0.43 & 5.24 & 4.76 & 3.37 & 21.83 \\
$\mathrm{~m}^{2}$ & 0.68 & 0.36 & 0.1 & 1.01 & 0 & 1.1 & 0.66 & 1 & 0.72 \\
$1000 \mathrm{kWh}$ & 0.21 & 0.03 & 0.02 & 0.12 & 0 & 0.52 & 0 & 0.07 & 0.12 \\
$\mathrm{~m}$ & 0.14 & 0.02 & 0.88 & 0.04 & 0 & 0.04 & 0.03 & 0.02 & 0.09 \\
units & 25.98 & 35.29 & 40.16 & 28.9 & 0 & 28.58 & 18.87 & 32.42 & 40.7 \\
pairs & 0.56 & 0.25 & 0.05 & 0.96 & 0 & 0.92 & 0.04 & 0.92 & 0.93 \\
liters & 3.47 & 0.23 & 0.09 & 0.54 & 0 & 0.35 & 0.06 & 6.87 & 15.93 \\
kg & 59.37 & 50.26 & 57.4 & 65.09 & 99.57 & 62.75 & 75.58 & 55.23 & 19.53 \\
thousand & 0.69 & 0 & 0.01 & 0.33 & 0 & 0.5 & 0 & 0.1 & 0.15 \\
units & & & & & & & & & \\
\hline
\end{tabular}

Source: Tariff line Database, United Nations Statistical Division.

\section{The processing METHOdology of The TRADE UNIT VALUES DATABASE}

The Trade Unit $V$ alue database is constructed by processing the raw tariff lines data. The objective is to provide a World-level dataset reporting reliable unit values at a high level of disaggregation. The above description of the tariff line data has illustrated some issues that have to be solved in the raw data to compute reliable unit values. This section describes the processing methodology we used to construct the Trade U nit V alue database.

\subsection{Subtotals and reporting thresholds}

The first step in our data processing consists in removing totals, subtotals and zero trade flows when they appear in the data. Trade flows reported using a nomenclature that is not compatible with the Harmonized System classification are also dropped.

As already mentioned, one important issue in the data is related to the existence of different reporting thresholds among reporters. Different reporting thresholds can indeed introduce some heterogeneity among reporters due to a statistical bias. To deal with this statistical issue, we impose a USD 1,000 reporting threshold on trade flows when they are aggregated into HS 6-digits categories (as in the Comtrade dataset). At the level of commodity codes, a second reporting threshold is set to USD 10.

$V$ alues and quantities of duplicates (same reporter, partner, commodity code, year) are aggregated in order to keep only one value and quantity for a given flow. 


\subsection{Conversion of quantities into weights}

Conversion factors are computed using UN Comtrade mirror flows (i.e. the quantity declared by the exporter is compared with the quantity declared by the importer). When quantities are declared in different units by the exporter and the importer, this provides an empirical conversion factor. A single conversion factor is computed by HS6 product code at the World level, on the basis of mirror flows. ${ }^{4}$

\subsection{Outliers detection and treatment}

Our procedure to detect outliers takes advantage of the distribution of unit values in the cross section, and the evolution of unit values over time. First, a median unit value is computed by reporter, commodity code, and year. Outliers are identified if a unit value exceeds the median*100 or is below the median/100. Second, the time dimension in the data is used at the HS-6 digits level to compare the evolution of unit values over time, for a given reporterpartner-product combination. Our condition implies that a single unit value at time t cannot be a thousand times higher than the unit value of the same flow at time $t-1$ or $t+1$. When outliers are identified, the observation is dropped from the data so as to keep only reliable unit value information.

\subsection{Missing quantities}

As discussed in the introduction, our objective is to provide a database of unit values that improves the comparability and the reliability of each observation. This, however, tends to reduce the coverage: for many countries, the value of a trade flow is not associated with the corresponding weight in a large proportion of cases. In section 2.2, we showed how empirical conversion factors have been used to convert all quantities into weights. Hence, when quantity is available in any quantity unit, we are able to compute a trade unit value in terms of US dollars per ton.

When some value is declared but the quantity is missing, no unit value is a priori available. In this situation, several cases apply. If the reporter never reports any quantity information for the same commodity code, we leave the unit value as "missing". In the case where the quantity is missing for one flow, but is reported for the same commodity and reporter but different partners, the missing unit value is replaced by the average unit value weighted by the value of trade flows. For example, France may report the exported value and quantity of a certain category of cars, for all destinations but one. In this case, we compute the average unit value corresponding to exports of the sale category of cars by France. The missing unit value is then replaced by the average unit value. In using this strategy, we assume that the unit value is the same over all partners for a given commodity code, when information is missing. However, we do not impose that several reporters share the same unit value.

\footnotetext{
${ }^{4}$ A similar methodology is implemented to construct the BACI data. See Gaulier and Zignago (2010).
} 


\subsection{Aggregation}

All the steps that were discussed in the previous paragraphs describe how the raw tariff lines data are used to compute reliable unit values at the level of commodity codes. As discussed in the presentation of the raw data, in Section 1, most countries report international trade flows to the United Nations using their own product nomenclature. National nomenclatures generally correspond to the Harmonized System nomenclature augmented with additional digits that are specific to each country. Cross-country comparability therefore requires that all unit values are aggregated into the same HS 6-digits revision.

The HS-6 digits unit value is obtained, for each reporter and partner, by taking the average unit value over all commodity codes weighted by the quantity of each flow. This aggregation strategy relies on unit values information rather than on separate values and quantities. This allows keeping information of a better quality for HS 6-digits unit values, especially when quantities in weight are missing at the disaggregated level.

Different revisions of the Harmonized System nomenclature are used in the tariff line database. In order to allow comparison across countries and years, HS 6-digits level commodity code are converted into two different revisions, revision 1 (HS96) and revision 2 (HS2002), using correspondence tables from the U NSD. Export and Import data are separated in order to provide two different databases.

\section{The Trade Unit Values database}

\subsection{Description of the files}

The unit value database provides import (Cost Insurance Fret) and export (Free On Board) unit values using the Harmonized System of classifications with revisions 1996 and 2002. This results into four databases, each database being decomposed into 9 files corresponding to the years covered by the data (2000-2008).

Each file is coded using the following name: "UV_rev_rg_yr.csv" with rev the HS revision ("96" or "02"); rg the declaration regime (" $x$ " for exporter, " $m$ " for importer); yr the year (2000 to 2008).

The 5 variables specified in each file are:

- " $\mathrm{i}$ " the exporter;

- " $\mathrm{j}$ " the importer;

- "Hs6_rev" the hs6 code followed by the HS revision ("96" or "02");

- "Y $r$ " the year;

- "uv" the unit value in US dollars per ton; 
Table 6 below provides a brief description of the number of observations, reporters, partners, products and years in each of the four databases.

Table 6. Summary description of the four T rade Unit Values databases

\begin{tabular}{|c|c|c|}
\hline & HS96 & HSO2 \\
\hline CIF data & $\begin{array}{l}\text {-N umber of observations: } 35,221,995 \\
- \text { N umber of reporters: } 173 \\
- \text { N umber of partners: } 255 \\
\text {-N umber of products: } 5,113 \\
\text {-N umber of years: } 9\end{array}$ & $\begin{array}{l}\text {-N umber of observations: } 34,922,652 \\
-N \text { umber of reporters: } 173 \\
-N \text { umber of partners: } 255 \\
-N \text { umber of products: } 5,224 \\
\text {-N umber of years: } 9\end{array}$ \\
\hline FOB data & $\begin{array}{l}\text {-N umber of observations: } 33,653,044 \\
- \text { N umber of reporters: } 173 \\
\text {-N umber of partners: } 255 \\
\text {-N umber of products: } 5,113 \\
\text {-N umber of years: } 9\end{array}$ & $\begin{array}{l}\text {-N umber of observations: } 33,332,222 \\
-N \text { umber of reporters: } 176 \\
-N \text { umber of partners: } 255 \\
-N \text { umber of products: } 5,224 \\
\text {-N umber of years: } 9\end{array}$ \\
\hline
\end{tabular}

Source: Trade U nit V alue Database - CEPII

The U nited Nations Statistical Division does not provide tariff line data for all countries since 2000. The number of reporters depends on the year (Table 7). The database covers the majority of countries since 2005 (more than 150). Table A1 in annex provides the time coverage of each country in the database.

Table 7. Summary description of the CIF import HS96 Trade Unit Values database

\begin{tabular}{ccccc}
\hline & observations & reporters & partners & products \\
\hline 2008 & 5621584 & 145 & 252 & 5113 \\
2007 & 5611642 & 152 & 252 & 5113 \\
2006 & 5143860 & 156 & 251 & 5113 \\
2005 & 4990446 & 157 & 253 & 5113 \\
2004 & 3767429 & 119 & 254 & 5113 \\
2003 & 3047800 & 99 & 252 & 5113 \\
2002 & 2607517 & 85 & 251 & 5113 \\
2001 & 2266510 & 75 & 250 & 5113 \\
2000 & 2165207 & 71 & 249 & 5113 \\
\hline \multicolumn{5}{l}{ Source: Trade U nit V alue D atabase - CEPII }
\end{tabular}

\subsection{T rade coverage of the database}

Despite our treatment of missing unit value in the database, there is still a large share of missing unit value. Table 8 below presents the coverage of our database, in proportion of the 
number of trade flows in the UN Comtrade database. The UN Comtrade provides values for all trade flows at the 6 digit level of the HS. Comparing the number of flows of the two databases gives the coverage of the $U$ nit $V$ alue database relative to all existing trade flows.

At the World level, unit values are available for, on average, $56 \%$ of the import trade flows. The coverage of the base is lower in the first years (44\% for 2000 ) than for the last one $(82 \%$ for 2008). The low number of reporters in the raw data for the early years explains this difference of coverage. Some heterogeneity can be observed across countries. For countries like the United States or China, unit values are observed for a small proportion of flows (respectively $56 \%$ and $57 \%$ ) whereas these countries are in the database for the entire period.

\section{Table 8. C overage of the CIF import HS96 Trade Unit V alues database compared to the UNSD C omtrade database}

\begin{tabular}{ccc}
\hline & $\%$ of flows & $\%$ of trade values \\
\hline 2008 & $82 \%$ & $79 \%$ \\
2007 & $82 \%$ & $79 \%$ \\
2006 & $75 \%$ & $78 \%$ \\
2005 & $74 \%$ & $80 \%$ \\
2004 & $64 \%$ & $69 \%$ \\
2003 & $54 \%$ & $64 \%$ \\
2002 & $48 \%$ & $62 \%$ \\
2001 & $43 \%$ & $57 \%$ \\
2000 & $44 \%$ & $55 \%$ \\
\hline Source: Trade U nit V alue Database - CEPII
\end{tabular}

\section{Validationtests of the Trade Unit Values database}

The objective of the Trade U nit $V$ alues database, as discussed in introduction, is to improve the reliability of trade prices that are used in a number of empirical investigations. In order to assess whether we reach this objective, we need a reference dataset. In this exercise, we choose the unit values computed from the UN Comtrade dataset as a counterfactual. The UN Comtrade is the closest dataset in terms of country and product coverage; it also uses the same raw data.

\subsection{M ethodological differ ences with Comtrade}

The procedure that is implemented to construct the Trade U nit V alues database differs from the UN Statistical Division processing methodology for the construction of Comtrade. 
Differences arise with respect to the aggregation strategy, the conversion of quantities into weights, the identification of outliers, and the treatment of outliers and missing weights. ${ }^{5}$

In the Comtrade dataset, values and quantities are aggregated into the HS 6-digits nomenclature separately, before unit values are computed. This procedure may bias unit value when some quantities are missing at a higher level of disaggregation (e.g. missing quantity increases unit value after aggregation). In our processing, unit values are computed at the highest level of the disaggregation and then aggregated in HS 6-digits categories, which reduces this bias.

When weights are missing but other quantity units are available, weights can be estimated using conversion factors provided by the declaring country or the Food and Agriculture Organization (FA O). As discussed in section 2, our strategy uses conversion factors computed using UN Comtrade flows, and allows a conversion in most of cases.

When outliers or missing weights are detected, UN Comtrade quantities are estimated using the mean unit value that is recorded for the same reporter and product category. This requires that both quantity and value information are recorded for the same exporter and product, but for a different destination. Our procedure is similar, but is implemented at the highest level of disaggregation of commodity code. When this estimation is not possible, a Standard Unit $V$ alue is computed at the World level, and combined with declared values to estimate quantity information. The Standard Unit V alue assumes that all countries share the same price for a given HS 6-digits product category. This processing allows to estimate all missing quantities, but potentially reduces the variance of unit values observed for a given product on a given market.

Table 9 below reports for the years 2000 to 2008 the share of estimated and non-estimated quantity information in the Comtrade data, using the "flag" information that can be downloaded together with the dataset. The table shows that around $20 \%$ of observations are associated with estimated quantity information (quantity unit, net weight, or both). Estimated quantities may represent a higher share of flows in some countries, like USA (33\%), where few quantities are declared in weight. For other countries like UK, only $4 \%$ of the flows have estimated quantities in the Comtrade dataset. Most importantly, according to the UN Statistical Division, about $60 \%$ of estimated quantities are obtained using the Standard U nit $V$ alue by product category as a reference. ${ }^{6}$ In that case, estimated unit values do not match country characteristics such as their unit production cost or the specialization of production along the quality ladder. This implies that empirical investigations that rely partially on estimated quantity information may suffer from important biases in the analysis.

\footnotetext{
${ }^{5}$ A ppendix section A 1 provides a full description of the different steps of the Comtrade methodology.

${ }^{6}$ See UNSD report (2009)
} 
Table 9. Share of estimated and non-estimated quantity information in Comtrade

\begin{tabular}{ccccc}
\hline $\begin{array}{c}\text { No estimation } \\
(\text { flag = 0) }\end{array}$ & $\begin{array}{c}\text { Quantity unit } \\
\text { estimated } \\
(\text { flag = 2) }\end{array}$ & $\begin{array}{c}\text { Net weight } \\
\text { estimated } \\
\text { (flag = 4) }\end{array}$ & $\begin{array}{c}\text { Both quantity } \\
\text { unit and net } \\
\text { weight } \\
\text { estimated } \\
\text { (flag =6) }\end{array}$ \\
\hline 2008 & $79 \%$ & $5 \%$ & $6 \%$ & $9 \%$ \\
2007 & $80 \%$ & $5 \%$ & $7 \%$ & $8 \%$ \\
2006 & $72 \%$ & $9 \%$ & $6 \%$ & $12 \%$ \\
2005 & $69 \%$ & $10 \%$ & $4 \%$ & $17 \%$ \\
2004 & $76 \%$ & $8 \%$ & $5 \%$ & $12 \%$ \\
2003 & $77 \%$ & $7 \%$ & $4 \%$ & $12 \%$ \\
2002 & $79 \%$ & $6 \%$ & $5 \%$ & $10 \%$ \\
2001 & $79 \%$ & $5 \%$ & $4 \%$ & $11 \%$ \\
2000 & $80 \%$ & $5 \%$ & $5 \%$ & $10 \%$ \\
\hline
\end{tabular}

Source: UN Comtrade

\subsection{Disper sion of unit values}

We now provide some empirical analysis regarding the dispersion of unit values in the Trade U nit V alues and Comtrade datasets. The objective is to show how Trade U nit V alues differs from existing datasets.

A simple correlation shows that the Trade Unit V alues and Comtrade unit values are highly correlated $(88 \%)$. We then compute the kernel density of unit values extracted from both datasets. Regarding the Comtrade dataset, we provide a density analysis using the full sample, the sample where quantity is not estimated (flag $=0$ or flag $=2$ ), and the sample where quantity is estimated (flag $=4$ or flag=6). The density associated with each dataset is presented in Figure 1. The density of the Comtrade data with estimated quantity reports a sharper peak, meaning that these data are more concentrated around the mean value. This can be explained by the estimation of quantity information in Comtrade, which relies in many cases on a Standard U nit V alue by product category. This also explains why the full Comtrade dataset also reports a sharper peak. When quantities are not estimated in Comtrade, the shape of the density is similar as what is observed for the Trade $U$ nit $V$ alues. 
Figure 1. K ernel density of the logarithm of unit values in Trade Unit Values (TUV) and Comtrade (CT) databases in 2007

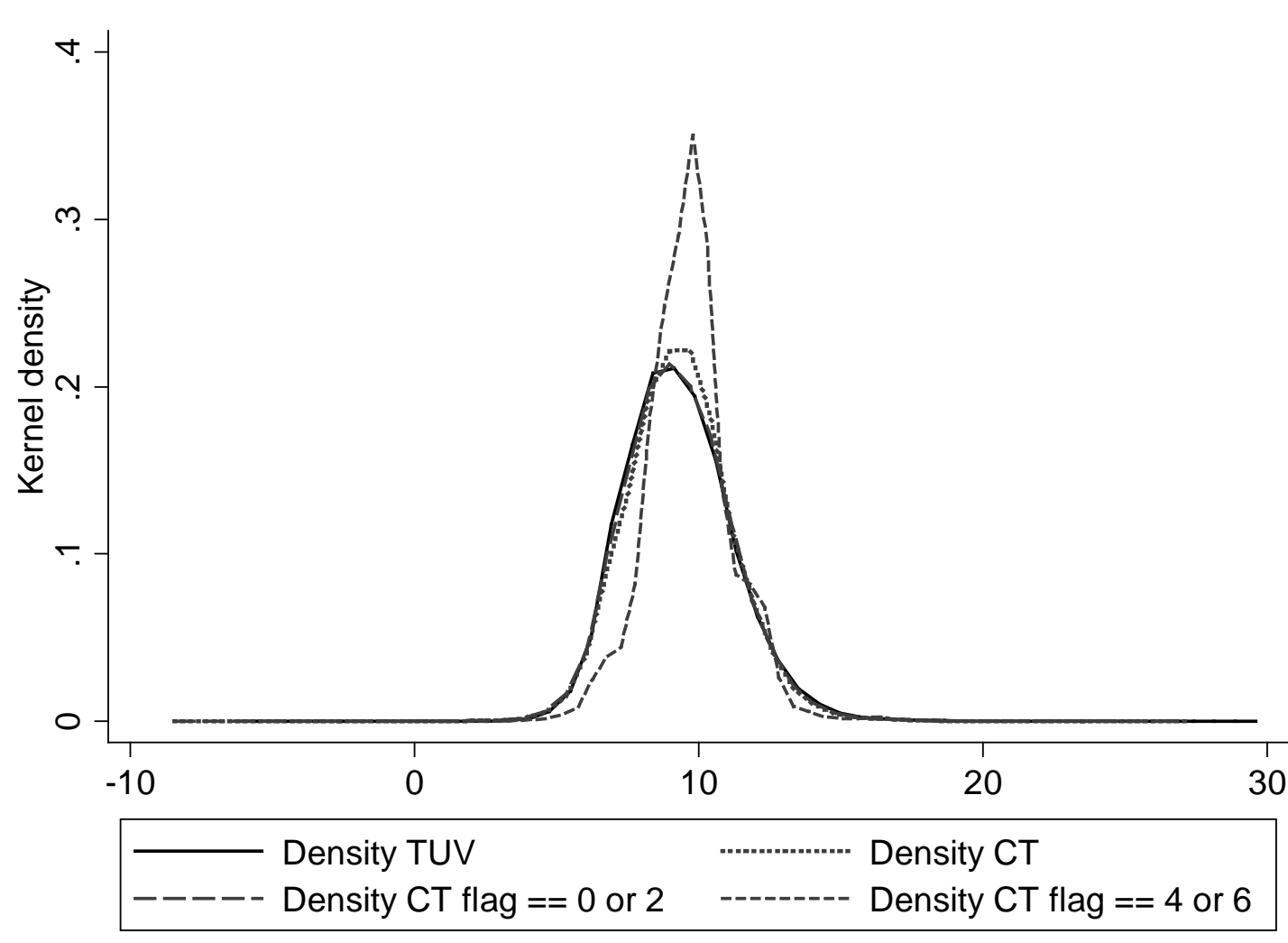

Note: The density distribution is based on the log of unit values in each database. CT $=$ Comtrade, TUV $=$ Trade Unit V alue

Source: A uthor's Calculations

In a second step, we describe the standard deviation of unit values within each product category in the Trade U nit V alues and Comtrade databases. The median standard deviation of unit values by HS 6-digits product code is computed for the year 2007. We also report the first and third quartiles in order to provide a more accurate picture of trade price dispersion within product categories.

Figure 2 starts the analysis using the full Comtrade dataset, and Comtrade subsamples relying on estimated quantities (flag $=4$ or 6 ) and non-estimated quantities (flag $=0$ or 2 ). As expected, the estimation of quantities in Comtrade dramatically reduces the standard deviation of unit values within each product category. This is even more the case within product categories where trade price dispersion is more important ( $3^{\text {rd }}$ quartile). 
Figure 2. M edian standard deviation of the unit values within HS 6-digits product categories, Comtrade dataset (2007)

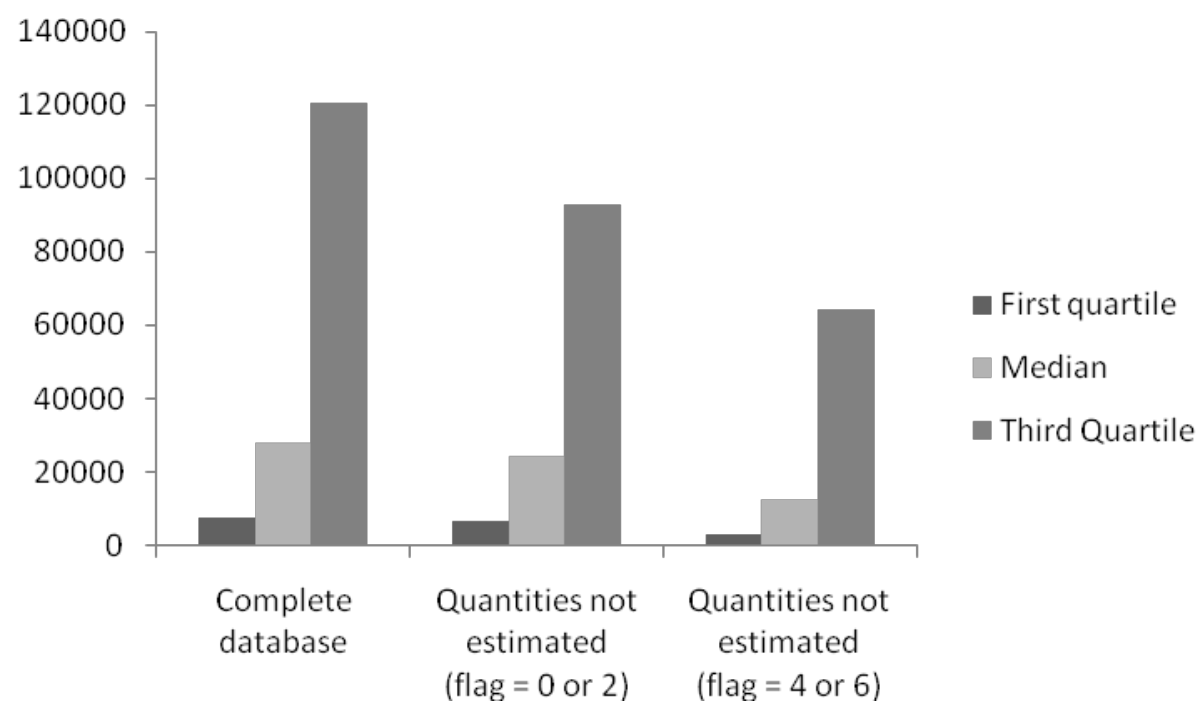

N ote: The standard deviation of unit values is computed by HS 6-digits product and year using the CIF unit values with the HS96 revision. Numbers are expressed in US dollars per ton. The top $1 \%$ of unit values was removed within each HS6 product category to drop outliers.

Source: A uthor's Calculations

Figure 3 uses both the Comtrade and Trade Unit Values datasets, relying on the same coverage in terms of observations. The median standard deviation of unit values is found to be comparable in the Trade U nit V alues and Comtrade datasets dataset (around 25 thousand US dollars per ton in 2007). The difference in terms of price dispersion between the two databases, however, is more important when we consider product categories with a high standard deviation of unit values. $25 \%$ of product categories have a standard deviation higher than 84 thousand US dollars in the Trade U nit V alues database, against 75 thousand US dollars in the Comtrade database with a similar coverage (i.e. price dispersion increased by $12 \%$ among product categories with higher price differentiation). The Trade U nit V alues dataset therefore offers a higher dispersion of trade prices, in product categories with more differentiation. 
Figure 3. M edian standard deviation of the unit values within HS 6-digits product categories, Trade Unit V alues and Comtrade databases with similar coverage (2007)

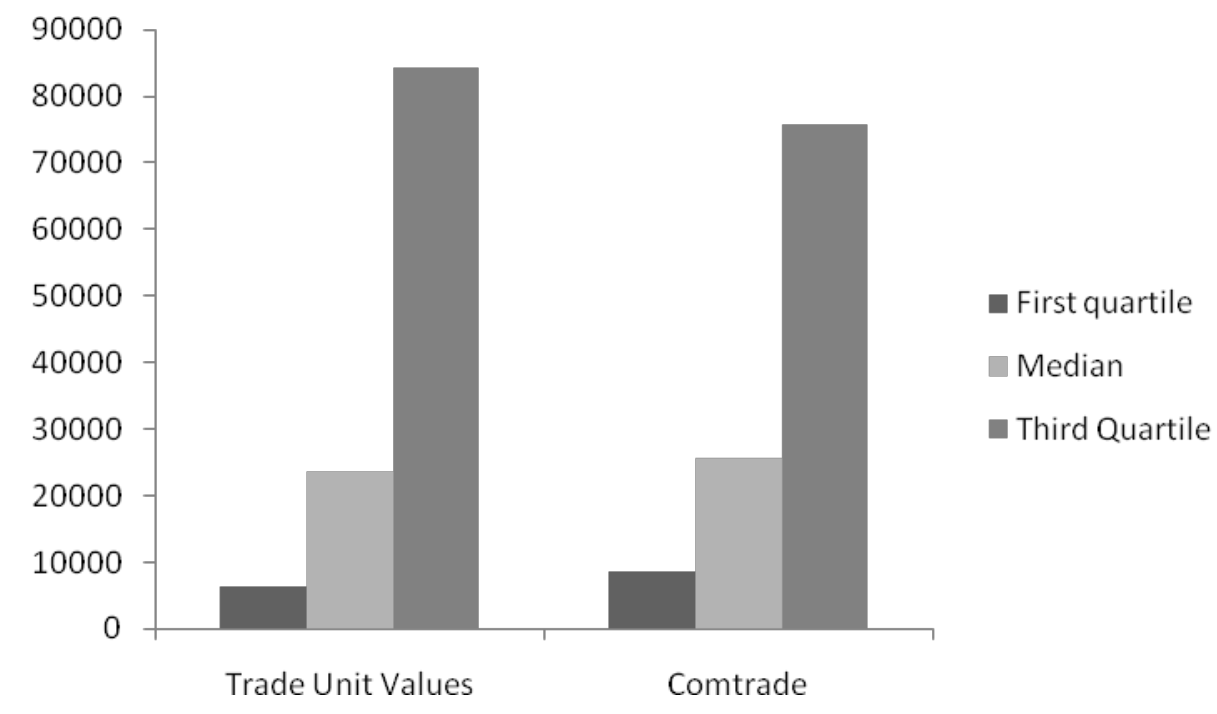

N ote: The standard deviation of unit values is computed by HS 6-digits product and year using the CIF unit values with the HS96 revision. Numbers are expressed in US dollars per ton. The top 1\% of unit values was removed within each HS6 product category to drop outliers.

Source: A uthor's Calculations

\subsection{E conometric analysis}

In order to assess the reliability of the Trade Unit $V$ alues dataset, we estimate the effect of economic aggregates on unit values from the Trade U nit $V$ alues and Comtrade datasets. We replicate the econometric analysis proposed by Fontagné et al. (2008). CIF unit values are explained by geographical distance and by the GDP per capita of both source and destination countries. GDP per capita of both the exporter and importer are traditionally expected to have a positive influence on trade prices, as well as the geographical distance between the two countries. Estimation results are provided controlling for product fixed effects. We use both the Trade U nit V alues and Comtrade datasets for the years 2005, 2006 and 2007.

Results in Table 10 show that CIF unit values are positively related to geographical distance and GDP per capita in all specifications. The R-square is similar in estimations using the Trade U nit $V$ alues and Comtrade datasets (columns 1 and 2). Considering the sample of unit values that rely on non-estimated quantities in Comtrade (column 3, flag $=0$ or 2), and estimated quantities in Comtrade (column 4 , flag $=4$ or 6 ), the R-square is much larger in the 
last column. The reason is that when quantities are estimated in Comtrade, most of the variance is explained by product fixed effects since unit values are mostly product-specific. ${ }^{7}$

\section{Table 10. R elation between CIF unit values and economic aggregates controlling for product fixed effects (2005-2007)}

\begin{tabular}{|c|c|c|c|c|}
\hline Database & $\begin{array}{c}(1) \\
\text { Trade Unit V alue }\end{array}$ & $\begin{array}{c}(2) \\
\text { Comtrade }\end{array}$ & $\begin{array}{c}(3) \\
\text { Comtrade } \\
\text { (flag }=0 \text { or } 2)\end{array}$ & $\begin{array}{c}(4) \\
\text { Comtrade } \\
\text { (flag }=4 \text { or } 6)\end{array}$ \\
\hline Dependent variable & \multicolumn{4}{|c|}{ CIF unit value } \\
\hline R-squared & 0.548 & 0.534 & 0.509 & 0.744 \\
\hline Idist & $\begin{array}{c}0.080 * * * \\
(0.006)\end{array}$ & $\begin{array}{c}0.056^{* * *} * \\
(0.006)\end{array}$ & $\begin{array}{c}0.071 * * * \\
(0.006)\end{array}$ & $\begin{array}{l}0.008 * \\
(0.005)\end{array}$ \\
\hline Igdp_cap_i & $\begin{array}{c}0.228 * * * \\
(0.006)\end{array}$ & $\begin{array}{c}0.199 * * * \\
(0.005)\end{array}$ & $\begin{array}{c}0.233^{* * * *} \\
(0.006)\end{array}$ & $\begin{array}{c}0.050 * * * \\
(0.003)\end{array}$ \\
\hline Igdp_cap_j & $\begin{array}{c}0.160 * * * \\
(0.005)\end{array}$ & $\begin{array}{c}0.169 * * * \\
(0.005)\end{array}$ & $\begin{array}{c}0.202 * * * \\
(0.005)\end{array}$ & $\begin{array}{c}0.033 * * * \\
(0.003)\end{array}$ \\
\hline Observations & $14,039,499$ & $16,755,796$ & $13,678,977$ & $3,062,331$ \\
\hline Product fixed effect & Y es & Y es & Y es & Y es \\
\hline Y ear dummies & Y es & Y es & Y es & Y es \\
\hline
\end{tabular}

Notes: Coefficients obtained with OLS estimation of the equation. Significance levels: ${ }^{* * *}$ at $1 \%, * *$ at $5 \%, *$ at $10 \%$. Standard errors clustered by country pairs. Estimation includes year dummies.

Differences in the R-squares between the Trade U nit V alues dataset and the Comtrade Dataset in Table 10 can possibly be explained by differences in the composition of observations. In Table 11, the estimation is performed using the Trade $U$ nit $V$ alues database and the Comtrade database, sharing the same coverage in terms of observations (11.9 million). The first two columns report estimation results without product fixed effects whereas columns (3) and (4) use product fixed effects. Finally, columns (5) and (6) report estimation results including product fixed effects, where the sample relies on non-estimated quantities in Comtrade. $W$ ithout product fixed effects, the $R$-square of estimations relying on the Trade $U$ nit $V$ alues and Comtrade datasets are similar, and share comparable coefficients on GDP per capita and geographical distance. When product fixed effects are included, however, the R-square of the estimation using the Comtrade dataset (column 4) appears larger the estimation relying on the

\footnotetext{
${ }^{7}$ This is due to the use of «standard unit values » by product category to estimate missing quantity in Comtrade. In unreported estimations without product fixed effects, the R-square for estimations relying on Comtrade unit values with estimated quantity is lower than in alternative subsamples.
} 
Trade $U$ nit $V$ alues dataset (column 3). This is explained by the fact that part of the unit values observations in Comtrade rely on quantities estimated using standard unit values. When we remove observations where quantity is estimated in Comtrade (columns 5 and 6), the Rsquare remains similar for estimations that rely on the Trade Unit Values and Comtrade samples.

Overall, these results show that although the dispersion of trade prices is larger in the Trade $U$ nit $V$ alues database, the power of explanation of the empirical model that we estimate, using bilateral distance and the GDP per capita of both partners as explanatory variables, is not reduced. This result implies that the larger dispersion in the Trade Unit V alues database is well explained by economic aggregates. This econometric analysis confirms that our processing improves the reliability of unit values, as a proxy for trade price.

\section{Table 11. Relation between CIF unit values and economic aggregates using the Trade Unit V alues and Comtrade datasets with a similar coverage (2005 - 2007)}

\begin{tabular}{|c|c|c|c|c|c|c|}
\hline $\begin{array}{l}\text { Database } \\
\text { Sample }\end{array}$ & $\begin{array}{c}(1) \\
\text { Trade U nit } \\
\text { Value } \\
\text { Inters }\end{array}$ & $\begin{array}{l}\text { (2) } \\
\text { Comtrade } \\
\text { ection }\end{array}$ & $\begin{array}{c}\text { (3) } \\
\text { Trade Unit } \\
\text { Value } \\
\text { Inters }\end{array}$ & $\begin{array}{l}\text { (4) } \\
\text { Comtrade } \\
\text { ection }\end{array}$ & $\begin{array}{c}(5) \\
\text { Trade U nit } \\
\text { Value } \\
\text { Intersection, } \\
2 \text { in Co }\end{array}$ & $\begin{array}{l}\text { (6) } \\
\text { Comtrade } \\
\text { flag }=0 \text { or } \\
\text { mtrade }\end{array}$ \\
\hline $\begin{array}{l}\text { Dependent } \\
\text { variable }\end{array}$ & \multicolumn{6}{|c|}{ CIF unit value } \\
\hline R-squared & 0.060 & 0.064 & 0.553 & 0.622 & 0.608 & 0.612 \\
\hline Idist & $\begin{array}{c}0.197 * * * \\
(0.008)\end{array}$ & $\begin{array}{c}0.192 * * * \\
(0.007)\end{array}$ & $\begin{array}{c}0.069 * * * \\
(0.007)\end{array}$ & $\begin{array}{c}0.068^{* * *} \\
(0.006)\end{array}$ & $\begin{array}{c}0.076^{* * *} \\
(0.006)\end{array}$ & $\begin{array}{c}0.077 * * * \\
(0.006)\end{array}$ \\
\hline Igdp_cap_i & $\begin{array}{c}0.266 * * * \\
(0.008)\end{array}$ & $\begin{array}{c}0.242 * * * \\
(0.007)\end{array}$ & $\begin{array}{c}0.235 * * * \\
(0.006)\end{array}$ & $\begin{array}{c}0.211 * * * \\
(0.005)\end{array}$ & $\begin{array}{c}0.232 * * * \\
(0.006)\end{array}$ & $\begin{array}{c}0.231 * * * \\
(0.006)\end{array}$ \\
\hline Igdp_cap_j & $\begin{array}{c}0.191 * * * \\
(0.007)\end{array}$ & $\begin{array}{c}0.188 * * * \\
(0.006)\end{array}$ & $\begin{array}{c}0.163 * * * \\
(0.005)\end{array}$ & $\begin{array}{c}0.160 * * * \\
(0.005)\end{array}$ & $\begin{array}{c}0.176 * * * \\
(0.005)\end{array}$ & $\begin{array}{c}0.176^{* * *} \\
(0.005)\end{array}$ \\
\hline $\begin{array}{l}\text { Observations } \\
\text { Product fixed } \\
\text { effect } \\
\text { Y ear dummies }\end{array}$ & $\begin{array}{c}11,947,093 \\
\text { No } \\
\text { Y es }\end{array}$ & $\begin{array}{c}11,947,093 \\
\text { No } \\
\text { Y es }\end{array}$ & $11,947,093$ & $11,947,093$ & $10,442,510$ & $10,442,510$ \\
\hline
\end{tabular}

Notes: C oefficients obtained with OLS estimation of the equation. Significance levels: ${ }^{* * *}$ at $1 \%, * *$ at $5 \%, *$ at $10 \%$. Standard errors clustered by country pairs. Estimation includes year dummies. 


\section{CONCLUSION}

This paper presents the methodology followed to construct the Trade Unit V alues database provided by the CEPII. This database relies on raw data for trade values and quantities at the highest available level of disaggregation (tariff lines). We believe that our processing strategy improves the reliability of unit values data for bilateral international trade, as compared to existing datasets.

Unit values are used by researchers as a proxy for trade prices. Unit values are, however, subject to a number of statistical biases, due to the aggregation issues and the treatment of missing quantity information in worldwide trade datasets. Our strategy relies on highly disaggregated trade data (tariff lines) and improves the aggregation of unit values into HS 6digits product categories. Contrary to existing datasets, most unit values in our dataset do not rely on the estimation of missing quantity information. We also implement a correction of outlier unit values. Overall, we improve the dispersion of unit values, for a given product category, as compared to observations in Comtrade. A simple econometric application shows that this high dispersion of unit values is well explained by a standard gravity model. Our strategy therefore improves the reliability of unit values as a proxy for trade prices.

The Trade U nit $V$ alues database therefore allows a better comparability of trade prices, in a given market and for a given year. This new database can therefore improve the empirical works dedicated to the study of price discrimination across markets, and the specialization of countries on vertically differentiated varieties. 


\section{BIBLIOGRAPHY}

Paulo Bastos and Joana Silva, 2008, "The Quality of a Firm's Exports: Where you Export to M atters," Discussion Papers 08/18, University of Nottingham, GEP.

Christian Broda \& David E. Weinstein, 2006, "Globalization and the Gains from Variety," The Quarterly J ournal of E conomics, M IT Press, vol. 121(2), pages 541-585, M ay.

José Manuel Campa, Linda S. Goldberg and Jose Manuel González M ìnguez, 2005, "Exchange Rate Pass-Through to Import Prices in the Euro Area," CEPR Discussion Papers 5347, C.E.P.R. Discussion Papers.

Lionel Fontagné, Guillaume Gaulier and Soledad Zignago, 2008, "Specialization Across V arieties and North-South Competition", Economic Policy, 23 (53): 51-91.

Guillaume Gaulier and Soledad Zignago, 2010 "BACl: International Trade Database at the Product-level. The 1994-2007 V ersion", CEPII Working Paper N. 2010-23.

Holger Görg, László Halpern and Balázs Muraközy, 2010, "Why do within firm-product export prices differ across markets?," CEPR Discussion Papers 7708, C.E.P.R. Discussion Papers.

A mit K handelwal, 2009, "The Long and Short (of) Quality Ladders," NBER Working Papers 15178.

Kalina Manova and Zhiwei Zhang, 2010, "Export Prices across Firms and Destinations", mimeo Stanford University.

Julien M artin, 2009, "Spatial Price Discrimination in International M arkets," Working Papers 2009-21, CEPII research center.

M athias Reister and M arkie M uryawan, 2009, "Quantity and weight data in UN Comtrade", UN Comtrade background paper.

Peter K. Schott, 2008. "The relative sophistication of Chinese exports," Economic Policy, CEPR, CES, MSH, vol. 23, pages 5-49, 01.

United Nations Statistical Division (UNSD), 2009, "Quantity information of UN Comtrade" UNSD Report, Expert Group on International M erchandise Trade Statistics Second meeting N ew Y ork.

Chang Won and A lan L. Winters "How Regional Blocs A ffect Excluded Countries: The Price Effects of MERCOSUR", The A merican Economic Review Vol. 92, No. 4 (Sep., 2002), pp. 889-904. 


\section{APPENDIX}

\section{A 1. Country coverage in the Trade Unit V alue database}

\begin{tabular}{|c|c|c|c|c|c|}
\hline & $\begin{array}{l}\text { number of } \\
\text { years in the } \\
\text { Unit Value } \\
\text { database }\end{array}$ & & $\begin{array}{l}\text { number of } \\
\text { years in the } \\
\text { Unit Value } \\
\text { database }\end{array}$ & & $\begin{array}{l}\text { number of } \\
\text { years in the } \\
\text { Unit Value } \\
\text { database }\end{array}$ \\
\hline Afghanistan & 1 & Germany & 9 & Panama & 4 \\
\hline Albania & 9 & Ghana & 5 & Papua New Guinea & 1 \\
\hline Algeria & 9 & Kiribati & 2 & Paraguay & 5 \\
\hline Andorra & 5 & Greece & 9 & Peru & 4 \\
\hline A ntigua and Barbuda & 4 & Greenland & 8 & Philippines & 9 \\
\hline Azerbaijan & 9 & Grenada & 5 & Poland & 5 \\
\hline Argentina & 9 & Guatemala & 4 & Portugal & 4 \\
\hline Australia & 5 & Guinea & 5 & Guinea-Bissau & 3 \\
\hline Austria & 9 & Guyana & 4 & East Timor & 2 \\
\hline Bahamas & 7 & Honduras & 6 & Qatar & 4 \\
\hline Bahrain & 7 & Hong $\mathrm{K}$ ong (SARC) & 4 & Taiwan, Province & 4 \\
\hline B angladesh & 8 & Hungary & 6 & Russian F ederation & 9 \\
\hline Armenia & 9 & Iceland & 4 & Rwanda & 5 \\
\hline Barbados & 9 & Indonesia & 7 & Saint Kitts and Nevis & 9 \\
\hline Belgium & 9 & Iran (Islamic Republic) & 7 & Anguilla & 8 \\
\hline Bermuda & 4 & Iraq & 3 & Saint Lucia & 7 \\
\hline Bhutan & 2 & Ireland & 8 & Saint V incent and & 7 \\
\hline Bolivia & 4 & Israel & 4 & Sao Tome and Principe & 9 \\
\hline B osnia and Herzegovina & 6 & Italy & 9 & Saudi Arabia & 6 \\
\hline Botswana & 7 & Côte d'Ivoire & 6 & Senegal & 7 \\
\hline Brazil & 9 & Jamaica & 7 & Seychelles & 9 \\
\hline Belize & 9 & Japan & 4 & India & 9 \\
\hline Solomon Islands & 6 & Kazakstan & 9 & Singapore & 9 \\
\hline Brunei Darussalam & 1 & Jordan & 4 & Slovakia & 7 \\
\hline Bulgaria & 4 & Kenya & 4 & V iet Nam & 9 \\
\hline Burundi & 7 & K orea, Rep. of K orea & 8 & Slovenia & 9 \\
\hline Belarus & 9 & Kuwait & 8 & South Africa & 7 \\
\hline Cambodia & 6 & K yrgyzstan & 4 & Zimbabwe & 4 \\
\hline Cameroon & 7 & Lebanon & 5 & Spain & 4 \\
\hline Canada & 7 & Lesotho & 2 & Sudan & 9 \\
\hline
\end{tabular}




\begin{tabular}{|c|c|c|c|c|c|}
\hline Cape Verde & 6 & Latvia & 4 & Suriname & 9 \\
\hline Central African Republic & 2 & Lithuania & 9 & Swaziland & 7 \\
\hline Sri Lanka & 4 & Luxembourg & 4 & Sweden & 7 \\
\hline Chile & 9 & M acau & 4 & Switzerland & 7 \\
\hline China & 9 & M adagascar & 9 & Syrian A rab Republic & 4 \\
\hline Colombia & 4 & M alawi & 9 & Thailand & 9 \\
\hline Comoros & 8 & M alaysia & 5 & Togo & 7 \\
\hline M ayotte & 9 & $M$ aldives & 7 & Tonga & 8 \\
\hline Cook Islands & 6 & M ali & 8 & Trinidad and T obago & 5 \\
\hline Costa Rica & 6 & Malta & 5 & United Arab E mirates & 7 \\
\hline Croatia & 9 & M auritania & 9 & Tunisia & 9 \\
\hline Cuba & 5 & M auritius & 4 & Turkey & 9 \\
\hline Cyprus & 9 & M exico & 9 & Turks and Caicos & 4 \\
\hline Czech Republic & 9 & M ongolia & 4 & Tuvalu & 6 \\
\hline Benin & 4 & M oldova, Rep.of & 8 & Uganda & 9 \\
\hline Denmark & 9 & M ontserrat & 5 & Ukraine & 6 \\
\hline Dominica & 9 & M orocco & 4 & The former Y ugoslav & 9 \\
\hline Dominican Republic & 3 & M ozambique & 9 & Egypt & 4 \\
\hline Ecuador & 4 & Oman & 6 & United K ingdom & 9 \\
\hline El Salvador & 9 & Namibia & 5 & Tanzania, U nited & 7 \\
\hline Ethiopia & 5 & Netherlands & 9 & U nited States of & 9 \\
\hline Estonia & 9 & N etherland Antilles & 4 & Burkina Faso & 3 \\
\hline Faroe Islands & 8 & Aruba & 9 & Uruguay & 9 \\
\hline Fiji & 4 & New Caledonia & 6 & V enezuela & 5 \\
\hline Finland & 4 & V anuatu & 2 & Wallis and Futuna & 7 \\
\hline France & 9 & New Zealand & 4 & Samoa & 7 \\
\hline French Polynesia & 5 & Nicaragua & 6 & Y emen & 8 \\
\hline Gabon & 2 & Niger & 9 & Y ugoslavia & 5 \\
\hline Georgia & 8 & Nigeria & 3 & Zambia & 9 \\
\hline Gambia & 5 & Norway & 7 & & \\
\hline Occupied Palestinian & 9 & Pakistan & 5 & & \\
\hline
\end{tabular}




\section{A2. Summary of the quantity cor rection in Comtrade}

Starting in 2005, a new processing system has been implemented by the UN Statistical Division Comtrade with the aim of improving the coverage of quantity information. ${ }^{8}$ Q uantity information is estimated when quantity is simply missing, when quantity units do not match W orld Customs Organization recommendations, or when extreme values are detected. A II the processing that is presented below is performed using the raw tariff lines data aggregated at the HS 6-digits level for values and quantities separately.

\section{(i) Quantity units do not match World Customs Organization recommendations}

In order to allow international comparisons and comparisons in a given year, standard practice requires converting all quantity units into weights, when weights are not initially available. The UN Statistical Division uses empirical conversion factors provided by the declaring countries, or eventually by the FAO for agricultural commodities. When conversion factors are not available, weights are estimated using the procedure detailed below (paragraph iii).

\section{(ii) Detection of extreme quantities}

The detection of extreme quantity information relies on unit values, with two criteria. First, a unit value is identified as an outlier if it exceeds the maximum historical value $* 10$ or is below the maximum historical value/10. The maximum historical value correspond to the maximum of the average unit value for a given reporter and product for the last five years. The second detection criteria uses the concept of the "Standard U nit V alue". ${ }^{9}$ The Standard Unit $V$ alues is the median unit value of a product, computed at the world level. The unit value has to lie in a range that is bounded by the standard unit value* 2 and the standard unit value/2.

(iii) Estimation of quantities for extreme and missing weights

When weights information is missing or detected as extreme, the raw quantity (missing or not) is replaced by an estimated one. Let us label i the reporter country, j the partner country, $k$ the product, and $t$ the year. A first level of treatment uses, for a given reporter-product-year (ikt), the average unit value computed from reliable trade flows (W eighted Unit $V$ alue). The trade value of the "suspect" quantity is then combined with this average unit value to estimate the new quantity. A second level of treatment uses a Standard U nit V alue computed at the W orld level, for each product $k$, using information from the previous year. This standard unit value is simply the median unit value at the World level. In this case the value flow of the "suspect" quantity is combined with the Standard Unit V alue to estimate the new quantity. Importantly, this second level of treatment is implemented in the case where the first one fails.

\footnotetext{
${ }^{8}$ See the UN Comtrade companion paper by Reister and Muryawan (2009), and the UNSD Report "Quantity information of UN Comtrade" in N ovember 2009.

${ }^{9}$ See the A nnex II of Reister and M uryawan (2009).
} 
This methodology is extremely useful to provide comparable information on quantity across countries, within detailed product categories. However, it also narrows the heterogeneity of unit values across countries of the same good category, for two reasons: first, extreme quantities are detected using the same unit values criteria for all countries. Then, the second level of treatment for the "suspect" quantities (detailed above) assumes the same unit value for all "suspect" flows for a given product. 


\section{LIST OF WORKING PAPERS RELEASED BY CEPII}

An Exhaustive list is available on the website: IIwww.cepii.fr.

No Title

2011-09 Carbon Price Drivers: Phase I versus Phase II Equilibrium

\section{Authors}

A. Creti, P.-A. Jouvet $\&$ V. Mignon

2011-08 Rebalancing Growth in China: An International A. Bénassy-Quéré, Perspective

B. Carton \& L. Gauvin

2011-07 Economic Integration in the EuroM ed: Current Status J. J arreau and Review of Studies

2011-06 The Decision to Import Capital Goods in India: Firms' A. Berthou \& M. B as Financial Factors M atter

2011-05 FDI from the South: the Role of Institutional Distance M. A leksynska and Natural Resources $\&$ O. Havrylchyk

2011-04b What International Monetary System for a fast- A. Bénassy-Quéré changing World Economy?

$\&$ J. Pisani-Ferry

2011-04a Quel système monétaire international pour une A. Bénassy-Quéré économie mondiale en mutation rapide? $\quad \&$ J. Pisani-Ferry

2011-03 China's Foreign Trade in the Perspective of a more G. Gaulier, F. Lemoine Balanced Economic Growth \& D. Ünal

2011-02 The Interactions between the Credit Default Swap and V. Coudert \& M. Gex the Bond $M$ arkets in Financial Turmoil

2011-01 Comparative Advantage and Within-Industry Firms M. Crozet \& F. Trionfetti Performance

2010-33 Export Performance and Credit Constraints in China J. Jarreau \& S. Poncet

2010-32 Export Performance of China's domestic Firms: The F. Mayneris \& S. Poncet Role of Foreign Export Spillovers 
No

\section{Title}

Authors

2010-31 Wholesalers in International Trade

M. Crozet,

G. Lalanne

$\&$ S. Poncet

2010-30 TVA et taux de marge : une analyse empirique sur $P$. Andra, M. Carré données d'entreprises

\& A. B énassy-Quéré

2010-29 Economic and Cultural Assimilation and Integration M. Aleksynska of Immigrants in Europe $\& Y$, Algan

2010-28 Les firmes françaises dans le commerce de service

G. Gaulier, \& D. M irza

E. Milet

2010-27 The world E conomy in 2050: a Tentative Picture J. Fouré,
A. Bénassy-Quéré
\& L. Fontagné

2010-26 Determinants and Pervasiveness of the Evasion of $S$. Jean Customs Duties

$\&$ C. M itaritonna

2010-25 On the Link between Credit Procyclicality and B ank V. Bouvatier, Competition

A. Lopez-V illavicencio \& V. Mignon

2010-24 A re Derivatives Dangerous? A Literature Survey

G. Capelle-Blancard

2010-23 BACl: International Trade Database at the Product- G. Gaulier Level - The 1994-2007 Version \& Soledad Zignago

2010-22 Indirect Exporters F. McCann

2010-21 Réformes des retraites en France: évaluation de la $X$. Chojnicki mise en place d'un système par comptes notionnels $\quad \&$ R. M agnani

2010-20 The Art of Exceptions: Sensitive Products in the Doha C. Gouel, C. Mitaritonna Negotiations \& M.P. Ramos

2010-19 Measuring Intangible Capital Investment: an V. Delbecque A pplication to the "French Data" $\quad \&$ L. Nayman

2010-18 Clustering the Winners: The French Policy of L. Fontagné, P. Koenig, Competitiveness Clusters

F. M ayneris $\& S$. Poncet 
No Title

Authors

2010-17 The Credit Default Swap M arket and the Settlement V. Coudert \& M. Gex of Large Defauts

2010-16 The Impact of the 2007-10 Crisis on the Geography G. Capelle-B lancard of Finance $\&$ Y . Tadjeddine

2010-15 Socially Responsible Investing: It Takes more than G. Capelle-B lancard Words

$\&$ S. Monjon

2010-14 A Case for Intermediate Exchange-Rate Regimes

V. Salins

\& A. B énassy-Quéré

2010-13 Gold and Financial A ssets: A re they any Safe Havens V. Coudert in Bear M arkets?

$\&$ H. Raymond

2010-12 European Export Performance $\quad \begin{aligned} & \text { A. Cheptea, L. Fontagné } \\ & \& \text { S. Zignago }\end{aligned}$

2010-11 The Effects of the Subprime Crisis on the Latin G. Dufrénot, V. Mignon American Financial Markets: An Empirical \& A. Péguin-Feissolle A ssessment

2010-10 Foreign Bank Presence and its Effect on Firm Entry O. Havrylchyk and Exit in Transition Economies

2010-09 The Disorted Effect of Financial Development on A. Berthou International Trade Flows

2010-08 Exchange Rate Flexibility across Financial Crises V. Coudert, C. Couharde $\&$ V. M ignon

2010-07 Crises and the Collapse of World Trade: The Shift to A. B erthou Lower Quality

C. Emlinger

$\&$

2010-06 The heterogeneous effect of international outsourcing Fergal M cCann on firm productivity

2010-05 Fiscal Expectations on the Stability and Growth Pact: M. Poplawski-Ribeiro Evidence from Survey $D$ ata

\& J.C. Rüle

2010-04 Terrorism Networks and Trade: Does the Neighbor J. de Sousa,

D. M irza Hurt

$\&$ T. V erdier 


$\begin{array}{lll}\text { No Title Authors } & \end{array}$

2010-03 Wage Bargaining and the Boundaries of the M. Bas \& J. Carluccio Multinational Firm

2010-02 Estimation of Consistent M ulti-Country FEERs $\quad$ B. Carton \& K. Hervé

2010-01 The Elusive Impact of Investing A broad for Japanese L. Hering, T. Inui Parent Firms: Can Disaggregation A ccording to FDI \& S. Poncet Motives Help 